\title{
Application of plants in remediation of contaminated sites
}

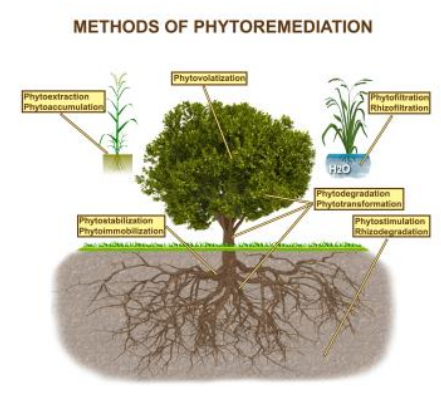

ARTICLE INFO

Citation:

Stanković D, Devetaković J (2016)

Application of plants in remediation of contaminated sites. Reforesta 1: 300-320.

DOI: http://dx.doi.org/10.21750/R EFOR.1.15.15

Editor: Vladan Ivetić, Serbia Received: 2016-02-03 Accepted: 2016-05-04

Published: 2016-05-25

\section{CrossMark}

This article is Chapter 14 of establishing issue of Reforesta Journal, edited in form of Thematic Proceedings, by Vladan Ivetić and Steven Grossnickle.

Copyright: (C) 2016 Stanković Dragica, Devetaković Jovana. This work is licensed under a Creative Commons Attribution-

NonCommercial-ShareAlike 4.0 International License.

\author{
Dragica Stanković ${ }^{\bowtie}$, Jovana Devetaković \\ University of Belgrade, Faculty of Forestry, Kneza Višeslava 1, Belgrade \\ $\underline{\text { dragica.stankovic@sfb.bg.ac.rs }}$
}

\begin{abstract}
The concern for environmental protection has existed since the time of first human civilization. As society develops, the chain of changes during the natural flow of processes in ecosystems has been supplemented by a new link - pollutants. They have an effect on all other members of the ecosystem (changes may be visible immediately or harder to spot), which leads to an extremely complex relationship with nature. The values of some parameters of pollutants reached an alarmingly high level. The tendency to reduce the risk of air, soil, water, plant, and animal pollution to a tolerable limit, which would salvage the environment and most importantly human health, became a global problem. Heavy metals as pollutants have been an interest of researchers for their conduct, especially in forest ecosystems, which has been expressed in the previous year's more than ever. With its numerous toxic effects, heavy metals are endangering the existence of plant species that live in already contaminated environments. This is all an argument regarding the fight of modern society that the emission of polluted materials gets reduced in order to avoid multiple negative effects, which can endanger the existence of living organisms in general, as an argument for the continuation of numerous researches that are conducted in this area. The monitoring of heavy metals is of significant importance because their toxicity and accumulations are vital for the ecosystem. Polluted soils can be reduced and they can restore their function using physical, chemical, and biological techniques. Physical and chemical methods are very expensive and cause mainly irreversible changes, thus destroying biological variety. The biological recovery of contaminated soil represents an efficient method of reducing health risks for both mankind and the ecosystem. For this purpose, biological indicators are used. Numerous researches have led to improvements of the initial idea about using plants as a remediation of the environment and the removal of different contaminants from contaminated medias into promising technologies of environmental protection under the title "Phytoremediation". This technology consists of the reduction of concentrations of polluted materials in polluted soils, water, or air. Plants have the ability to store, degrade, or eliminate metals, pesticides, solutions, explosives, and crude oils. Its derivatives and various other contaminants form mediums that contain them. This paper especially considers methods of the possibility of the usage and application of plants in restoring soil contaminated by heavy metals as well as other pollutants.
\end{abstract}

\section{Keywords}

Phytoremediation, Degradation, Plants, Environment, Reforestation 


\begin{tabular}{|c|c|c|}
\hline \multicolumn{3}{|c|}{ ontents } \\
\hline 1 & Introduction & 301 \\
\hline 2 & Forest degradation and deforestation & 304 \\
\hline 3 & The importance of microelements for the development of plants & 304 \\
\hline 4 & The preservation of soil resources & 306 \\
\hline 5 & Phytoremedation & 309 \\
\hline & 5.1 Advantages and disadvantages of phytoremediation & 309 \\
\hline & 5.2 Methods of phytoremedation & 311 \\
\hline & 5.2.1. Phytoextraction & 311 \\
\hline & 5.2.2. Phytostabilization & 312 \\
\hline & 5.2.3. Phytofiltration & 313 \\
\hline & 5.2.4. Phytovolatilization & 313 \\
\hline & 5.3 Plants in phytoremediation & 315 \\
\hline 6 & Conclusions & 316 \\
\hline 7 & Acknowledgments & 317 \\
\hline 8 & References & 317 \\
\hline
\end{tabular}

\section{Introduction}

The ecological situation is getting worse worldwide. Soils are increasingly degrading due to excessive use of chemical products. Scarcity of drinking water is increasing every day and deforestation takes on immense proportions. In the next few decades, negative impacts are expected to double. Deforestation leads to an increase of carbon dioxide concentration in the atmosphere, which leads to an even greater instability when it comes to the climate and its changes. As a consequence, habitats and ecosystems are destroyed, which leads to the mass pollution of the environment.

Ecological crises in recent decades have been formed as a separate topic and represent very serious warnings of endangerment of basic foundations regarding human existence. In the middle of the twentieth-century, major changes of industrial processes have led to a change in form of pollution, which led to the fact that in the second half of the twentieth-century, pollution increased considerably faster than during industrial production. Industrial pollution is especially dangerous because it affects the whole environment (Ponting 1991).

For a century now, internal combustion engines were evaluated only by the criteria of the number of horsepower forces that is produced per liter of fuel consumed; the rest was not important. The industrialized world continued this for nearly a century, unwilling to accept the fact and pay attention to the millions of cubic meters of exhaust gasses that have contaminated the atmosphere during the XX century (Obradović et al. 2007). Solving global ecological problems is not possible without a multidisciplinary approach to those very complex issues related to this field.

Just a few decades ago if we typed into a computer 'eco-remediation', 'phytoremediation' etc., we would get virtually no response, whereas current knowledge has vastly increased. Gradually, environmentalism, especially in areas of conservation, preservation, and improvement of the environment, is developing more and more. Today, we are witnessing environmentalism penetrating all aspects of social life, trying to gradually form an awareness among people regarding the importance of the protection and improvement of the environment.

The basic idea that plants can be used for the remediation of environmental media is very old, thus, the original reference is unknown. The importance of plants as 
hyperaccumulators of heavy metals began to gain importance only a couple of decades ago.

Any form of environmental pollution inevitably leads to an increase of harmful substances, not only in the air, but also in the soil and plants, and as a consequence, in food. The level of general pollution of some areas often depends solely on local pollution from human activities.

If basic ways in the development of environmental protection from degradation and destruction can be generally defined and presented, we have to start all operations from the beginning. The development of environmental protection can, and should be, directed in three directions classified according to the following activities or stages:

1. Taking multidisciplinary measures and activities in order to reduce all sources and forms of environmental pollution (at all levels),

2. Improving technology and technological processes in order to reduce the creation of all kinds of pollutants and

3. Develop a method of removing pollutants from all environmental media for the purpose of its sustainability.

Among the many issues that arise in the environment, one of the most serious is without a doubt soil degradation and destruction of forest ecosystems (Stanković et al. 2008, 2011, 2013, 2014, 2015). Preventing and stopping the degradation or decrease of degraded soil, afforestation is practiced; that is, the use of technologies that can guarantee good success, and with the possibility of a small investment. It is necessary to promptly establish new young forests on degraded land or on areas where they recently did not exist, because forests and forest soil were located on impact of factors causing their degradation and, in extreme cases, disappearance.

Planting forests can be defined as: 1) reforestation; as artificial forest regeneration by planting seedlings following harvest and 2) afforestation; as a way of increasing forest coverage and methods of restoring forests after deforestation (Ivetić 2015). Reforestation is facing new challenges, mainly due to drought and extreme weather conditions. Reforestation programs must take projections of climate changes into consideration (Ivetić and Devetaković 2016). Stopping degradation and decrease of degraded soil involves the application of technology of afforestation, which guarantees a good success with a smaller investment (Isajev et al. 2010).

Restoring forest vegetation is in many cases very successful, but we cannot ignore the fact that the use of plant species for soil protection from various forms of degradation has a large number of limiting factors. Afforestation of degraded land has long-term effects. Although the effects are visible only in later years, we can say that each newly planted tree is a gift to future generations. Beside the well-known economic importance of afforestation, it has a priceless ecological significance (Stanković et al. 2013a; Šijačić-Nikolić 2012). Climate changes and other causes of changes in the environment cause different forms and intensities of degradation of biological communities and habitats.

Chain of changes of natural processes in ecosystems has been supplemented with new links- pollutants, which have an effect on all other members of the ecosystem. Changes can be immediately visible or hidden for a longer period of time. They too undergo some changes, which leads to the already complex relationships in nature to get even more complicated (Trivan et al. 2010; Stanković et al. 2014).

Given the fact that ecological conditions are variable i.e. individual components of the environment are changing seasonally and on an annual basis, only by 
environmental monitoring can we achieve anything. Permanent monitoring allows the realistic assessment of the state, which primarily draws attention to the problem before it becomes too serious. It helps us understand what needs to be taken into consideration in order for this problem to be solved in the quickest way possible. All this clearly indicates the importance that every day without activities aimed at preserving the environment is, in fact, a missed opportunity to do something in favor of environmental protection.

Nature taught us that even the most serious environmental problems have solutions. Pollutions of habitats with heavy metals is one of the major environmental problems, because it has an extremely negative impact on the environment and humans, therefore, it is necessary to find an efficient and cost-appropriate solution as soon as possible.

As already stated, there is no accurate data as to when plants have first been used for the removal of pollutants from different mediums. Numerous data and a series of scientific discoveries, combined with inter and multidisciplinary approaches to research, led to the development of ideas of promising technologies for environmental protection called phytoremediation. Greater attention and interest to enlarge the content of pollutants on plants and in the soil has been given at the end of the fifties of the last century. Primault (1958) published the first paper on the impact of exhaust gasses on plants. His research was mainly focused on understanding and taking note of the current situation. Operations of this kind are generally of informative character. It would be impossible to mention all of the authors of scientific works in this field, for as the list would go on forever, but we must mention the following: Daines et al. (1970), Motto et al. (1970), Keller (1985), Kloke et al. (1966), Johnson (1980), Treshowa (1980), Schultz (1987). The monitoring of heavy metals is particularly important because harmful effects, calculated annually, of all of these metals exceed the overall harmfulness of radioactive and organic waste generated each year (Nriagu 1979; Pacyna 1989).

The dangers of pollution of different ecosystems, the orographic conditions as important factors that significantly affect the level of accumulation of heavy metals in the soil and on plants, and the meteorological aspects of pollution of the atmosphere are all topics that the following local authors address (Gburčik et al. 1994; Jović et al. 1995; Kadović and Medarević 1996; Đordjevic 1996; Krstić et al. 2006)

Kurfurst (1989) and Guthner (1989) point out; because of the negative effects heavy metals have on the biosphere, including the harmful effects that they have on living organisms, which increases due to long-term exposure and cumulative effects, researchers are paying more attention to this problem.

The problem of afforestation on polluted grounds is very complex and cannot be taken lightly. This problem must be addressed accordingly with the help of a large number of multidisciplinary scientists and experts from various fields. A large number of activities can be sprung into action as well. One of the most important steps or actions in forestation is an appropriate and proper selection of plant species. According to Tomić (2004): "The correct choice of species for successful forestation cannot be carried out without the knowledge of the natural forest vegetation of the locality. Many unsuccessful forestation attempts in the past lead to the sooner or later deterioration of cultures due to the introduction of domestic and foreign species in inappropriate habitat. Therefore, it is necessary to make a plan for forestation defining potential 
natural vegetation or, to ensure a higher success rate complete forest ecosystems are to be relied upon to make the correct choice of taxon and technology of reforestation."

\section{Forest degradation and deforestation}

Deforestation in the world has grown to such proportions that it is necessary to adequately respond and prevent its extinction. The motives of exploiting this important natural resource vary. Mostly man has always destroyed forests. Unplanned cutting, followed by harmful insects, rodents, and fires are all factors that lead to the destruction of forests. In the past, we have witnessed many uncontrolled forest fires in the world, leaving unforeseeable consequences and leading to national disasters. In addition to its many activities and interventions in nature, humans are causing deforestation. By polluting our environment, we are indirectly destroying the existing forest ecosystems. Different types of pollutants are causing the degradation of forest ecosystems. This is one of the reasons that a serious approach regarding the reforestation of degraded habitats by multiple types of pollutants should be addressed cautiously.

According to the National Forest Inventory of the Republic of Serbia (Ministry of Agriculture, Forestry, and Water Management), published in 2009, 29.1\% of the Republic of Serbia is covered by forests and other woodlands. By international definition this includes $4,9 \%$ covered by scrubs and bushes, coming to a total amount of $34.0 \%$ (or $36.3 \%$ compared to the surface of the productive land in the Republic of Serbia). In the structure of forest resources, the tree species are predominant with sawmills (59\%), followed by mixed forests $(29.3 \%)$, pure stands conifers $(8.7 \%)$, mixed forests and sawmills (2.4\%) and mixed conifer forests (0.6\%). The national Forest Inventory of the Republic of Serbia confirmed that there are 49 tree species; deciduous species (40) dominate over the coniferous (9). Balkan beech is the most dominant tree in the forests of the Republic of Serbia followed by Turkey oak, Sessile oak, Hungarian oak, Hornbeam etc. The standing volume was $333,404,423 \mathrm{~m}^{3}$ and $159 \mathrm{~m}^{3} \mathrm{ha}^{-1}$, the total annual increment is $8,222,129 \mathrm{~m}^{3}$ or $3.9 \mathrm{~m}^{3} \mathrm{ha}^{-1}$. The Regional Plan of Serbia is expected to reforest 1.35 million hectares of mainly barren land by 2050, with the hope of achieving $41.4 \%$ of optimal forest coverage of Serbia (49.8\% Central Serbia, Vojvodina 14.32\%, Kosovo and Metohija 52.6\%) (1996). Vojvodina is the most fertile agricultural land; $83.5 \%$ of its area is used for agriculture. Creating new forest plantations, forest care in all stages, afforestation, and abandoned pastures, as well as the conversion of degraded coppice forests to better habitats in high economic forests, are all top priority task when it comes to improving the state of forests. Successfully raising and properly caring and cultivating forests on contaminated/degraded habitats are the biggest problem require a large number of scientific methodology and experts.

\section{The importance of microelements for the development of plants}

Plants can be viewed as a complete system. They are inseparably linked to certain physiological - biochemical processes and a series of local tissues where a coordinated activity is performed, thus allowing us to view them as a whole and unique system. For these reasons, it is necessary to intensively study and find the conditions in which the hereditary potential will most likely succeed, that is, in which conditions harmonious optimum will be reached in said plants. We must not forget to take into consideration the environmental conditions that have an influence on plants. On the 
other hand, we should pay particular attention to the creation of certain specific genotypes for which it is possible to define the conditions of cultivation to a maximum exploitation of their biological potential.

In nature, plants are often exposed to many negative factors (stress) that may have an impact on their growth and development. These stress factors can be biotic (imposed by other organisms) and abiotic (caused by physical or chemical changes in the environment). For a long time, it was thought that growth and development i.e. physiological - biochemical processes in plants (except for hydrogen, oxygen, carbon, and nitrogen) need an additional six minerals: phosphorus, potassium, calcium, magnesium, sulfur, and iron. Out of these elements, the following three were found to have a wide practical use as fertilizers: nitrogen, phosphorus, and potassium (Krstić et al. 2011).

Scientific developments have contributed in the revelation of a series of microelements that are essential for plants to function normally. They are required in very small amounts measured in $\mu \mathrm{g}$ or ppm (parts per million). Among the most important microelements are: boron, zinc, manganese, copper, molybdenum, nickel and cobalt. Chlorine and aluminum, as well as other elements, are necessary for some higher plants, whereas algae need vanadium, gallium, scandium, and tungsten. These discoveries have helped explain a series of phenomena in plants that emerged. Either as certain phenomena classified into diseases, or as phenomena that led to abnormal morphological and anatomical changes. It should be noted that in this area of the specific effects of microelements on physiological and biochemical processes still has unexplained facts regarding their necessity and biological function. These questions will continue to be a problem for future scientific research. The problem of the critical period of plants compared to the microelements remains barely studied, but these critical moments do exist. For some microelements, these are the earliest stages of plant growth, for others it is the period of the formation of the reproductive organs and reproduction itself, and for the third period, accumulation of spare substances in corresponding organs. The way we use microelements is of great significance because their effect depends on various factors (Oljača 2014; Stanković et al. 2015).

Based on previous statements, it is evident that microelements should be strictly specific. We must keep in mind the characteristics of the soil, the content of microelements in the soil accessible to plants, the physiological characteristics of different species and varieties and so on. The circulation of mineral substances is extremely important, particularly in natural forests. The shortest is the cycle at which the rain due to the rotting litter rinses elements, as well as from excrements of insects that eat leaves. Decomposed leaves and branches provide minerals that are released for a period of several weeks or months in warm climates, up to several years in cold areas. Large branches and trees that are rotting for decades, which means that it depends on the durability (quality) of timber and microbial degradation of biomass conditions.

It is also a known fact that in this environment it should be noted that the mat of sawmills is easier decomposed at the same conditions of sawmills mats, which accelerates the development of the fauna land and has better humus properties. This indicates that the stands of conifers should be entered with deciduous trees. Due to the increasing demand for wood, wood price increases and the cost of entry of mineral fertilizers decreased. In addition to spatial planning of stands, besides nutrients, it is a necessary rule for a given habitat at the establishing forests to choose plant varieties and clones of plant species. The greatest experience gained with the poplars and 
willows, whose harvest cycle is about 20 years and which are increasingly used in phytoremediation, before other species for absorption of all heavy metals from polluted sites (Krstić et al. 2008, 2011).

In pine forests of temperate-zone higher proportion of nitrogen and minerals from the forest litter enters the cycle after 20 years. Out of the total amount of adopted mineral matter from the mat, $80 \%$ goes to the education of leaves and $15 \%$ on the education of tree branches. In the case of tropical climate, more than $40 \%$ of $\mathrm{Na}, \mathrm{K}, \mathrm{Ca}$ and $\mathrm{Mg}$ from the soil humus $30 \mathrm{~cm}$ thick enters the circulation cycle. In such conditions, the tissue of plants containing $30 \%$ nitrogen, that were exchanged $50 \%$ of calcium and magnesium, $60 \%$ of the exchanged potassium found and $90 \%$ of phosphorus (Sarić et al. 1991).

\section{The preservation of soil resources}

Conservation of land resources is mans responsibility to nature. In the last two decades, multidisciplinary study of the land area is very realistic in the world and in our country. The problem with these studies is that they are extremely complex and require continuous work of experts of different areas (ecology, biology, physiology, forestry, agronomy, geology, pedology, phytocenology, metereology, economy etc.) in order to find and use reliable parameters for defining space in terms of quantity and quality. The ultimate goal is to get defined land space to be used optimally from the social and economic point of view. A multidisciplinary evaluation of lands in forestry has a special significance, because the interests of forestry are intertwined with the interests of agriculture, water management, energy industry, transport, urban planning, hunting economy etc. Soil, as a natural resource, should be regarded as a nonrenewable resource, formation and renewal of the geological base needs thousands of years, until the period of its degradation or loss can sometimes be brief and measured within seconds or minutes, for example, in the case of erosion or in some other natural or anthropogenic accidents (Tomić et al. 2011).

In fact, as one polydisperse, dynamic system, vital for all human activities, it allows the maintenance of global ecosystem, which has a strong environmental impact on other elements of the environment including groundwater and surface water, then to human health and food safety. Land is an important source of carbon, which affects the transformation of plant nutrients, which allows maintenance of the overall biodiversity in the country, but otherwise, represents a space for all human activities, among those activities which are related to the supply of organic and mineral raw materials, and most importantly, food production.

Unlike others environmental media, soil is static and has a great capacity to accept large volumes of pollutants that remain in it for many years so that the effects of pollution are long hidden and require a trigger in order for pollutants from the land to transfer to other environmental media. If adequate attention wasn't paid to land degradation, especially when it comes to contamination by heavy metals, pesticides, radionuclide and other hazardous materials from various sources, it could cause the appearance of the so-called "Chemical time bomb", which is comparable to the metastasis of cancer in the human body (Sekulić et al. 2003).

In the territory of the Republic of Serbia, of the total surface $86.4 \%$ of the territory is affected by degradation of different types and intensities. On inclines over $5 \%$, it is affected $70 \%$ of the territory. The mountainous area is dominated by water and 
wind, while erosion is dominant in flat areas. By existing calculations, each year in the Republic of Serbia sediment is produced $37,300,000 \mathrm{~m}^{3}$, of which 9.35 million $\mathrm{m}^{3}$ (25\%) is deposited in water accumulations or other water ecosystems (NAP 2014).

The quality of the soil is affected by inadequate agricultural practices, including uncontrolled and inadequate use of fertilizers and pesticides, as well as the lack of control of the quality of water used for irrigation (most often waters which are to a significant degree contaminated). Widespread use of petrol causes soil contamination lead along by the main roads. Poor management of waste and chemicals cause soil degradation (by taking space and the emission of harmful and hazardous substances which penetrate the soil profile). A special type of degradation was taking place during the NATO bombing in the form of mechanical damage of land, by depleted uranium pollution, soil contamination by petroleum derivatives (Stanković et al. 2011a; Stanković et al. 2012).

The basic natural processes of soil degradation are water erosion and wind erosion; the loss of organic matter, compaction through increasing volume of weight (density) and of porosity of decline soil; Salinization through the accumulation of soluble salts in the soil; landslides caused by slipping on slopes, that is moderately fast or fast movement of land masses and rocks.

Due to the exploitation of mineral resources, especially in open cast mines, the land has completely degraded. This is particularly noticed in the Kolubara $\left(44^{\circ} 26^{\prime} 10^{\prime \prime} \mathrm{N}\right.$, $\left.20^{\circ} 20^{\prime} 39^{\prime \prime} \mathrm{E}\right)$ and Kostolac $\left(44^{\circ} 42^{\prime} 18^{\prime \prime} \mathrm{N}, 21^{\circ} 13^{\prime} 35^{\prime \prime} \mathrm{E}\right)$ basins, where lignite has been removed, which is considered the best agricultural land.

Permanent loss of agricultural land in the Republic of Serbia is related to the urbanization and development of infrastructures (eng. "sealing soils"). Although there is no data on this class of soil, which type of exploitation this is affecting, spreading zones of urban centers and working activities (development of urban and rural settlements, roads, building of factories, mines, hydro power plants, the construction of the airport, borrow pits, etc.) are related mainly to the fertile, lowland soil, on whose periphery comes and with depopulation which migrates in the urban area (NAP2014).

Heavy metals are naturally found in the soil, but lately their concentration in soil increased suddenly due to various human activities. The presence of heavy metals in the soil is constant, but their level and behavior, and thus mobility and accessibility for plants depends on many factors: parent material, soil reaction, content of organic matter and clay in the soil, mechanical soil composition, moisture, content of calcium and carbonates et cetera. Regardless of the chemistry and dynamics of individual elements, if the concentration of heavy metals in the soil is significantly higher than usual, it indicates contamination either from the anthropogenic sources or from their natural geochemical origin. Control of soil levels proceeds via comparison with MAC (maximum allowed concentration) of unpolluted soil, which directly determines the quality of the soil itself.

In Vojvodina according data of examined soils, with regard to the content of heavy metals, are well below permissible levels. Overall, in the area of Vojvodina, even with stricter criteria that were lowered than MAC for the total content of heavy metals can be arranged by organic agriculture (Stanković et al. 2005; Stanković 2008). The situation in central Serbia is somewhat different, where the total content of heavy metals in some localities significantly exceeds the MAC. Elevated concentrations of heavy metals are not only anthropogenic origin, but are related to the geochemical origin and genesis of certain soil types. From the aspects of used value of these soils, 
however, approaches are conflicting, because the analysis of plant material of cultivated crops in the area of central Serbia showed that an exclusively higher overall (pseudototal) content of these elements in the soil, and that it is affordable fraction of these elements for plants minor. These results are consistent with the results related to similar serpentine soils in the world (NAP 2014).

Pollution with heavy metals is present in the vicinity of major industrial facilities. Usually it is regarding lead and zinc, where the tailings are deposited on the surrounding soils, where the wind blows soil and plants away. An extreme form of land degradation has been noted around thermal power plants due to broadcasting of aerosols and gases with $\mathrm{SO}_{2}$ and $\mathrm{NO}_{x}$, which the wind blows in the form of ash on the surrounding soils and plants. Potential contamination with arsenic is present in the area around the Bor mines (44 $\left.04^{\prime} 21^{\prime \prime} \mathrm{N}, 22^{\circ} 07^{\prime} 46^{\prime \prime} \mathrm{E}\right)$.

Heavy metals are predominantly retained in the organic surface layer, which is of great importance for the productivity of ecosystems. Research has shown that the origin of heavy metals in soil is primarily geo-chemical, except for land in industrial

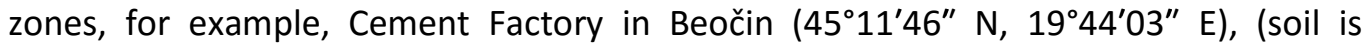
contaminated with nickel), battery factory in Sombor $\left(45^{\circ} 45^{\prime} 21^{\prime \prime} \mathrm{N}, 1^{\circ} 07^{\prime} 07^{\prime \prime} \mathrm{E}\right)$ (soils

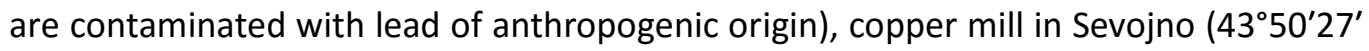
$\mathrm{N}, 19^{\circ} 53^{\prime} 18^{\prime \prime} \mathrm{E}$ ), (soil is polluted with copper and zinc), Mining and Smelting Complex (land contaminated with copper and arsenic).

The deposition of heavy metals contributes to the intensive acidification of forestland, so the basic components of forest ecosystems, flora and fauna, presents the receptors of heavy metals from water soil. That is why, in relation to the circular flow of matter, the undisputed risks present heavy metals in ecosystems (Fukuda et al. 2002). Heavy metals, radionuclides and other inorganic pollutants are one of the predominant forms of environmental pollutants and their remediation in soil, sediments and waters is quite a difficult job.

Based on the analysis of the Agency of Environmental Protection on the territory of Serbia by 2010, 375 locations where pollution is confirmed by laboratory analyzes of soil and groundwater in the vicinity of localized sources of pollution were identified. By analyzing the measures which were implemented on the identified sites, it was established that, on the majority of the locations, preliminary research was performed that included the identification of the site and determination of the presence of pollutants in the values above the allowed maximum, while at a few locations, detailed research was included. The remediation was performed on $5.7 \%$ identified locations. On locations where there is municipal waste has not been done in terms of research to confirm their effects on soil and ground water, so they were not considered in the quantification of progress in the management of contaminated sites. The largest share of the identified localities have public municipal landfills with $43.7 \%$, followed by oil extraction and storage of $26.4 \%$ and industrial and commercial localities with $16.3 \%$.

Which of the methods for the purification of land is going to be used for recovery of land depends on the species and the size of its contamination. The aim is to improve soil quality and prevent further penetration of pollutants into deeper layers and groundwater. Conventional methods for remediation of contaminated soil are based on the excavation, pumping out and transporting to another location where the latter is physically isolated by storage in barrels or by burying in deeper layers of the earth. These methods are expensive because of the energy consumption for excavation and transport. Also, the quality of land can be repaired at the source in a way that does not 
include relocation of soil, but perform a chemical treatment. Chemical remediation is based on stabilization, solidification, oxidation, but the question is of environmental acceptability of such methods because of the use of chemicals. And last, but not least, is the repair of land by planting suitable plant species that would influence the level of pollutants in the soil. Unlike many organic pollutants, most of heavy metals cannot be eliminated from the environment by chemical and biological transformation, and therefore the prevention of their entry into the environment must be taken into account and must continue to work on finding new alternative methods for their removal. One of such methods is certainly the new green tech-phytoremediation.

\section{Phytoremediation}

Phytoremediation as the term denotes the use of green plants for solving the problem of polluting the environment. Phytoremediation (lat. Phyto - plant and remedium - to clean, rebuild) indicates a large number of technologies that are based on the ability of plants to accumulate large quantities of metals that are naturally present in plant tissues, without causing symptoms of toxicity. It is a technology that is still developing, although many data and results are already present in the literature. It can be successfully combined with other biotechnologies, particularly when they are in the terms of contaminated sites with a complex problematic. This is a relatively new process of cleaning of all three environmental media. Its implementation started in the early ' 80 s and, to this day, has been tested on a number of areas worldwide.

Phytoremediation is an environmental friendly technology, which uses plants for decomposition, metabolism, or detoxification of various contaminants the environment (air, water, soil). Organisms involved in phytoremediation, besides plants, are microorganisms and fungi. Phytoremediation now includes a set of methods and techniques such as phytoextraction, phytostabilization, phytovolatization and others.

In determining which of phytoremediation techniques will be applied, we must take into account all environmental factors. For example, it is necessary to evaluate whether and how much applied methods of remediation will affect inter-specific relationships, especially if it will affect other crops. Considering that plants that were grown for phytoremediation should be subjected to the conditions of contaminated soil or water, other crops are unlikely to survive in such (for them toxic conditions), and will likely reach of for the competition problems.

\subsection{Advantages and disadvantages of phytoremediation}

The application of phytoremediation in our climate has a positive and scientific confirmation in situ and ex situ projects. In situ application is more common. The US Agency for Environmental Protection EPA (Pilipović et al. 2002) has defined phytoremediation as a technology that uses plants and their rhizosferic microorganisms to remove, degrade, or keep harmful chemical substances that are found in soil, groundwater and surface water, and in the atmosphere.

The commercialization of this new biotechnology is rather slow, primarily because of insufficient knowledge of the complex relationships that exist between the rhizosphere and mechanisms that are based on the ability of plants to adopt and translocate metals from polluted environment (Reichenauer 2002). One of the greatest advantages of phytoremediation as well as some other biotechnologies, such as 
bioremediation, is that it is one of the cheapest biotechnologies, which is also natural and "environmental friendly" (Lasat 2002).

Using phytoremediation does not further burden the environment, because such factors of purification are used on those types of plants, which normally can grow or are already growing on the given contaminated areas. Providing energy for this biotechnology takes place in a completely natural way because the plants use solar energy to the extent that is necessary for their growth, development, and performance of all physiological processes and mechanisms of phytoremediation (Pilipović et al. 2002).

The importance of phytoremediation in terms of preserving the environment is a major achievement. The large number of significant side effects, and of course, their importance varies depending on many factors and above all, which plant species are used in a given phytoremediation. For example, by planting tree species you can create so-called buffer zones, which can effectively reduce noise, then, to provide protection from the wind, to reduce carbon dioxide emissions into the atmosphere, to create new habitats for fauna development, or that on the end of the treatment represent a source of biomass for the harvest of trees. The success of phytoremediation depends primarily on the selection of the kind that would be applied in phytoremediation and it is a crucial step that determines the success of phytoremediation (Anderson 2002). Knowing the species, their entire ecology, and physiology and characteristics of their tissue and organs, i.e. anatomy and morphology of vital importance.

On one hand, the success of phytoremediation depends on many factors: the level of pollution, bioavailability, then the ability of plants to absorb and accumulate heavy metals in their bodies, and the type of plant used in phytoremediation. On the other hand there are limitations in terms of type of pollution (toxic substances) that are present in nature, as well as in its concentrations. If the concentration exceeds the capacity of the species tolerance to the toxic substance, it will function on it suppressive and possibly die. This especially applies to pollution originating from pesticides (Anderson 2002). Availability polluting substances of plants and its rhizosphere are also an important factor in the application of this technology. The root of the plants are most likely to adopt those molecules, ions, and atoms that are found dissolved in the soil solution.

Pilipović et al. (2002) point out the following disadvantages and limitations of phytoremediation:

- Application is limited to the shallow soil,

- Application is limited in certain types of watercourses,

- For each plant species there are pessimistic values of ecological factors including the terms of tolerance of plants according to toxic substances,

- The time period for conducting the removal of contamination from the environment is greater than with other methods, for example mechanical removal,

- Phytoremediation is effective only on moderately hydrophobic compounds,

- There is a potential danger of an entry of toxins into the food chain by entering the plant tissue with accumulated pollutants into animals and its further distribution through the food chain. 
Advantages of phytoremediation over other technologies for the removal of toxic metals from soil is that it is economically more cost effective due to a lower cost price. This technology does not lead to the degradation of ecosystems, as in the case with the implementation of other technologies for purification.

\subsection{Methods of phytoremediation}

Science distinguishes several methods or systems of phytoremediation. The technologies that use plants to remediate soil, sediments, and water polluted by heavy metals are (Prasad and Freitas 2003; Garde-Torresdey et al. 2005; Raskin et al. 1997; Cunningham et al. 1996):

\subsubsection{Phytoextraction}

1. Phytoextraction or Phytoaccumulation is the use of higher plants with the aim of using them to remove polluting substances, primarily heavy metals from soil (Lasat 2002). Phytoextraction involves the use of plants that accumulate metals and produce a lot of biomass, as well as the addition of chelating agents to soil in order to accelerate the process of transporting and the accumulation of heavy metals from the soil into aboveground parts of plants, which then will be removed through common cultural practices. In this method, the plants that are able to adopt pollutants by root system and translocation them to trees or leaves are mainly used. In herbaceous plants, after reaching a certain degree of growth and development, the harvest of biomass is carried out, thus removing part of the total quantities of heavy metals contained in the soil. Plants that are used for phytoextraction must be tolerant on metals that are removed and must be efficient in the translocation of the absorbed metals from the roots to the aerial portions of the plants, which will be mowed (Blaylock et al. 1997; Blaylock et al. 1999). According to numerous studies, herbaceous plant species are better accumulators of heavy metals in comparison to tree species. Also, the uptake of heavy metals by plants is carried out continuously during the vegetation period and during the year, reaching the highest value at the end of the vegetation period (Stanković 2008).

There are increasing attempts to use woody plants in the monitoring of environmental pollution, but the problem is the critical values for certain heavy metals, plant resistance on their presence, cumulative and possible synergistic functioning, as well as many other aspects that are less known (Stanković et al. 2013b; Stanković et al. 2014a). Trees are considered as a cheap, sustainable, and environmental friendly solution, especially when it is not cost effective to use other technologies or there is no time pressure for land use. Besides that, trees are improving amenity of the environment and provide wildlife habitat (Pulford and Watson 2003).

Some plants hyper-accumulative absorb large amounts of metal, unlike other plants. Natural hyper-accumulative of metals are plants that can accumulate and that can tolerate high concentrations of metals in outcrops without noticeable symptoms of intolerance. Hyper-accumulators have an increased amount of metals in outcrops: $1 \%$ zinc and manganese, $0.1 \%$ nickel, cobalt, chromium, copper, lead and aluminum, $0.01 \%$ cadmium and selenium, up to $0.001 \%$ live in total dry matter of biomass outcrops. It is known that plants have natural potential to remove heavy metals from the soil, such as $\mathrm{Cu}, \mathrm{Co}, \mathrm{Fe}, \mathrm{Mo}, \mathrm{Mn}, \mathrm{Ni}, \mathrm{Zn}$, which are in small amounts necessary for plant growth and development, but also the of $\mathrm{Cd}$ and $\mathrm{Pb}$, which certain types of plants also accumulate 
(although these elements have no known physiological activity in plant organism). According to numerous studies in Serbia (Krstić et al. 2006, 2007; Stanković et al. 2008, 2013a, 2014b), different plant species adopt different heavy metals, but in general it can be concluded that the following woody plants are good accumulators of heavy metals: sessile oak (Quercus petraea (Matt.) Liebl.) and wild cherry (Prunus avium L.) and of herbaceous species as accumulators, dandelion (Taraxacum officinale F.H. Wigg.) and nettle (Urtica dioica L.) particularly stand out. According to literature data, most hyperacumulators of lead is an Indian mustard (Brassica juncea L.) (Bakeret al. 1995), but also plants from other families such as Euphorbiaceae, Asteraceae, Lamiaceae and Scrophulariaceae.

It is necessary at this point to emphasize that heavy metals have different mobility within the trees, so lead, chromium, and copper usually remain immobilized in the roots, while cadmium, nickel, and zinc more easily move to the aerial parts of the plant. It is believed that poplar and willow represent a great potential when it comes to the use of trees in phytoremediation (Capuana 2011) because of its fast growth, high of biomass and high tolerance to heavy metals.

\subsubsection{Phytostabilization}

Phytostabilization is a process that uses a certain plant species in order to reduce the bioavailability of heavy metals in the environment. This is actually a process that uses plants to immobilize those contaminants that are found in the area between the root surface and the soil. According to that, the method of phytostabilization is successfully applied to stabilize (not clean) soil, sediments, and sledges' containing polluting substances in the root zone and deeper.

Species that have a high tolerance to heavy metals can be used to help restore vegetation on contaminated areas and also to minimize the spread of contaminants i.e. prevents the migration of pollutants either eolian, water erosion, rinsing, or even by dispersing in the soil. This process reduces the mobility of contaminants and prevents its migration to other environmental media. Phytostabilization takes place through the zone of the root system with microbiological or chemical mechanisms of the root zone itself, where it comes to a change in the chemistry of soil and / or polluting substances, such as a change of soil $\mathrm{pH}$, as a result of allocations exudate of the root system, or due to the formation of $\mathrm{CO}_{2}$. This process allows the reconstruction of the original vegetative cover in places where, due to the presence of high concentrations of metals natural vegetation, vegetation has disappeared.

Phytostabilization is applicable in circumstances where the amount of contaminants in the environment should be brought below the limit values. Highly contaminated soils are not suitable for phytostabilization because it is almost impossible for plant survival and growth. Advantages of phytostabilization are: that it is cheaper, easier to administer, it is not necessary the removal of soils that is its transfer to another location. This method is very aesthetic. Disadvantages of phytostabilizations are that pollutant matter itself remains on the ground and vegetation must be maintained with ameliorative measures and fertilization over a long period of time. The characteristics of the plants used in phytostabilization include tolerance to high amounts of contaminants which we want to stabilize, a high production of biomass of the root, which is capable of immobilizing the contaminant absorption, precipitation or reduction of the 
contaminant holding capacity and in root. This method is best used on fine-textured soils with high organic matter content.

\subsubsection{Phytofiltration}

Phytofiltration or rhizofiltration are methods of remediation of contaminated soil with which the root system of plants (rhizosphere) is used to perform absorption or adsorption of contaminants (mainly heavy metals) from the water or from waste water. The roots of such plants that grow in aerated water columns perform precipitation (sludge) and collects toxic contaminants of polluting effluents. In rhizofiltration, land plants are used (not water) because they create a much longer root system with welldeveloped root hairs that have a large surface area. Metals from post-industrial processes in wastewater of an industry and contaminated ground waters are removed by precipitation or flocculation, followed by sedimentation and residual sludge removal. Plants that are used in phytofiltration should be able to accumulate and tolerate high concentrations of the given metals, and should be suitable for manipulation and have low operating costs and a minimal amount of secondary waste. It is desirable to produce a large amount of root of biomass with a high surface area.

\subsubsection{Phytovolatilization}

Phytovolatilization is a process of adoption, transport, and release of pollutants, via the mechanism of transpiration in higher plants with the release of pollutants in the same, or modified form, in the atmosphere (EPA, 2000, cited in Pilipović et al. 2002). The initial phase is adoption of certain metals from contaminated soil, then their translocation and release into the atmosphere through the leaves. Some heavy metals (As, $\mathrm{Hg}$ and $\mathrm{Se}$ ) can be transferred into the environment in the gas phase. Researchers found natural or genetically modified plants capable of absorbing elementary forms of these metals from the soil, biologically translate them into gas phase inside the plant, and to release them into the atmosphere through the leaves. Volatilization of metals from the plant tissue allows the detoxification mechanism. We know that mercury and selenium are toxic, so the big question is whether this process is to be used as a method of remediation. Researchers who advocate this type of remediation point out that the phytovolatilization method minimally affects the land itself, reduces the possibility of erosion, and there is no need for disposing of contaminated plant tissue. It is used for the treatment of groundwater, soil, sediments, and sludges. When it comes to contaminated soil, it is necessary to have good water features in order for polluting substance to adapt. Also, all the factors that affect the flow of transpiration in plants (climatic conditions, temperature, precipitation, insolation, air pressure, and wind can significantly affect the efficiency and the amount of transparent polluting substances) can positively or negatively affect phytovolatilization. The problem with phytovolatilization is the possibility of accumulation of harmful metabolites and intermediate products in plant tissues and fruits that they can enter in food chain.

Some documents (ITRC 1999; US EPA 1999) in phytoremediation include other techniques such as:

a) Phytodegradation or phytotransformation - implies degradation of polluting substances by metabolic process of plants themselves, whereby to decomposition i.e. degradation may take place within the plant itself or in the environment of the plants 
under the influence of its enzyme (dehalogenaseoxygenase) or secretion of the enzymes only in the soil of plants (EPA 2000, cited in Pilipović et al. 2002).

Characteristics of molecules of polluting compounds and it solubility, hydrophobicity, and polarity are determined by the degree of the success of this biotechnology. Regarding polarity according to Bell (1992, cited in Pilipović et al. 2002) non-polar molecule with molecular weight below 500 will be attached to the root surface, while the polar molecule will be adopted and relocated. Pilipović et al. (2002) consider that the poplar could be successfully used for phytodegradation of trichloroethane, atrazine, TNT and fertilizers that are contaminated with groundwater. By using this method, plant chemical contaminant is modified in some non-toxic substances. Most often, it is used for harmful organic substances, pesticides, and explosives. Microorganisms in symbiosis with the roots of plants have the capability of metabolizing pollutants. The method of phytodegradation is useful in treating contaminated shallow soil, ground and surface waters, and in a wide range of climatic conditions. Advantages of this method are reflected in the fact that phytodegradation can be applied in those lands that do not have a viable and active micro flora, which would, through its activities, also be able to contribute to the decomposition of polluting substances. Disadvantage are the possibility of education of toxic metabolites and intermediate products metabolism, which must be strictly taken into account when allocating and implementing this method in practice.

b) Rhizodegradation - The increase of microbiological activity in order to degrade contaminants by adding certain substances in the soil. This process is known as rhizospheric degradation (stimulation of microorganisms) as phytostimulation. The bioactivity is derived from proteins and enzymes that can be produced by plants or organisms present in the soil, such as bacteria, yeast, and fungi. The organic contaminants, even those that are considered potentially dangerous to humans, such as some petroleum hydrocarbons, can be metabolized by these proteins and enzymes, which lead to degradation or mineralization of these contaminants. Besides, many of these contaminants can be degraded into harmless products or converted in a source of food and energy for the plants or organisms present in the soil. (Donnelly and Fletcher 1994). Rhizosphere degradation takes place in the land that is within immediate vicinity of the root system of the plants. It is microbial degradation of organic polluting substances which is aided by root systems of higher plants, because their own roots systems provide and secrete enzymes and organic substances (polysaccharides, amino acids, organic and fatty acids, growth factors) that stimulate the growth and reproduction of microorganisms and allow them to, through its activities, degrade polluting substances. On the other hand, the root system increases the surface area for the performance of degradation of polluting substances, then it improves the aeration of soil, moisture content in the soil, and in general contributes to the creation of optimal conditions for the effect of microorganisms. Advantages of this method are in situ conditions for the construction of polluting organic compounds, which contribute to significant savings of material resources in the rehabilitation of pollution, then reduces the possibility of transference of pollution from the soil into the plant and further into the food chain, or from plants into the atmosphere. Disadvantage of this method is that for the completion of this process lots of time is lost, which can be extremely unfavorable when contaminated soil has poor water-air, or mechanical characteristics, which additionally slows down the growth of microorganisms and their effects as well as the development of the very rooted row crops of plants. This type of 
phytoremediation is particularly effective for the degradation of organic compound originating from petroleum and petroleum products, followed by complex compounds of BTEX (benzene, toluene, ethyl-benzene and xylene), pesticides, etc.

Different types of phytoremediation can be successfully applied only if they fully satisfy all the criteria required for their successful implementation. Some of them are those related to characteristics of polluting substances, while some are related to the conditions of the contaminated location or properties of plants that are used in the treatment of pollution. Certainly basic and key criterion is the correct selection of species (Anderson 2002).

\subsection{Plants in phytoremediation}

Plants have a significant role in the removal of heavy metals, because they do not only acquire nutrients from contaminated habitats, but also can absorb and accumulate toxic elements. There are three ways for the adoption of heavy metals by plants:

- Actual exclusion (metals are not allowed to enter the plant),

- Exclusion of outcrops (metals accumulate in the root and translocation in outcrops is absent),

- Accumulation (metals accumulate in plant parts).

In doing so, the level of adoption of metals by plants and their tolerance to metals is highly variable from species to species (Raskin et al 1994; Krstić et al. 2011; Stanković 2011, 2014a). Marques (2009) says that the ideal plant that can be used for phytoextraction should have the following characteristics: tolerance to high concentrations of metals, developed root system, rapid growth, and the potential to produce a large biomass, as well as to accumulate high levels of metals in areas that can easily collect and further destroy, or take advantage of the excretion of metals.

According to Bhargava et al. (2012) and Peralta-Tube et al. (2009), plants that survive in soil saturated with metals can be placed into three categories:

1. Excluders - plant species that prevent the adoption of toxic metals in the root cells in which the concentration of metals in the aboveground parts kept below a critical value, ie. at a low level compared to the concentration in the soil. Excluders can be used to stabilize the soil and to avoid further spread of pollution associated with erosion.

2. Accumulators - types of plants where metals are concentrated in the aboveground parts. Accumulators do not prevent entry of metals into roots, and thus allow the bioaccumulation of high concentrations of metals in their tissues. 3. Indicators - types of plants in which the inner concentrations are proportionally reflected, ie. reflect external concentration.

It should be noted that a large number of plant species has under natural conditions mycorrhyza. The symbiosis with fungi have the potential to increase the absorption surface of the root and stimulate the adoption of nutrients and, among other things, of heavy metals (Khan et al. 2002; cited in Lasat 2002), but also to affect the transfer of heavy metals within the plant.

The mechanism of genetic control of processes of hyper-accumulating heavy metals in plant tissue is still not well understood, though scientific genetic studies have shown that the tolerance of plants to heavy metals are responsible for some major genes in their genetic maps (Macnair 1993; cited in Lasat 2002). 
Negative characteristics from the aspect of biotechnology in some plants are that most of plants that are hyper-accumulative are small and slow-growing species. Therefore, it is necessary to focus on genetic engineering in order to artificially correct these features. Brown et al. (1995a, cited in Lasat 2002) suggested transfer of genes are responsible for the phenotype of hyper-accumulating from species that are low and slowly growing in those that have high biomass production but low ability of hyperaccumulating heavy metals. The combination of high accumulation of metals and high biomass production gives the best results in the removal of metals. Short rotation coppice (SRC) can be used in the aim of phytoremediation (mostly willows). The high level of evapotranspiration of willows and tolerance of their root system to the anaerobic conditions make it possible to implement a high degree of irrigation communal wastewater (Ivetić and Vilotić 2014).

The selection of species of forest trees and shrubs take on special strategic importance for reconstruction and, according to the current objectives of forestry, requirements for the production of plants are imposed with desired characteristics in tree nurseries of trees and shrubs.

It is a fact that environmental pollution, especially chemical substances, is one of the most important factors of degradation of certain components of the ecosystem. Attempts to get pollution under control are as old as the problem itself, but the response to it has arrived late or was inadequate, as it is the human understanding of the consequences of pollution.

The last few decades, annually worldwide about 22,000 tones of cadmium, 939,000 tons of copper, 783,000 tons of lead and 1,350,000 tons of zinc (Singh et al. 2003) was released. Plants in which, due to extraction, a large amount of heavy metals has accumulated, must be properly taken care of after harvesting so the heavy metals in them would not once be again found free in the environment.

\section{Conclusions}

There are numerous studies and projects on the potential and possibilities for ways to improve the environmental situation in the world. In Serbia, the research and development should be directed towards the consideration what other countries are doing in this area. Practice reforestation should abandon patterns and adopted balanced choices with the terms of habitat types, i.e. the maximum use of habitat potential, both economic and environmental potentials a basic principle.

The key conclusion is that there are no great benefits of placing the established scientific theories, which are more or less elaborated and validated. After planting, the establishment of forest cultures and plantations have been only partially completed work on creating forests. Further care of forest cultures and plantations covers all the work that needs to be carried out in the woods and after their inception to the final cut.

Phytoremediation represents a technology of great significance, which makes the test of plant species with the capability of phytoaccumulation extremely important. It is a multidisciplinary technology on the rise, with a number of problems waiting to be solved, and the performance of each of these methods is impossible to achieve without the cooperation of scientists and experts in various fields, because the issue is multidisciplinary and highly complex. Attempts to bring pollution and environmental degradation under control are as old as the problem, but the answer to it is usually inadequate and arrived with a delay. In any case, we must be careful in the use of nature 
and its resources, and we must keep it in order to not realize the message by Ponting (1991) which says: "At the current stage of development, human society has two options: to many fuel-efficient and more carefully treat natural resources and the environment, or - you lose!

Forecasting that in the future, different pressures on the environment will develop, which have already been evolving for centuries, which is a difficult, almost impossible, job. Certainly it is evident that many problems await us. The fundamental problem in dealing with pollution is that there is no such technology that could prevent degradation. Therefore, it is necessary to try to find a balance between the demands of society and opportunities of nature and its resources to withstand all the pressures.

\section{Acknowledgments}

This paper was established as a part of the project "Establishment of Wood Plantations Intended for Afforestation of Serbia" (31041) financed by the Ministry of Education and Science of the Republic of Serbia within the framework Technological development from 2011-2016.

\section{References}

Anderson AT (2002) Development of a phytoremediation handbook: Considerations for enhancing microbial degradation in the rhizosphere. Institute of Environmental and Human Health, Texas Tech University, Texas.

Baker AJM, McGrath SP, Sidoli CMD, Reeves RD (1995) The potencial for heavy metal decontamination. Mining Environ Menager 3: 12-14.

Blaylock MJ, Salt DE, Dushenkov S, Zakharova O, Gussman C, Kapulnik Y, Ensley BD, Raskin I (1997) Enhanced Accumulation of $\mathrm{Pb}$ in Indian Mustard by Soil-Chelating Agents. Environ Sci Techn 31: 860-65.

Bhargava A, Carmona FF, Bhargava M, Srivastava S (2012) Approaches for enhanced phytoextraction of heavy metals. J Environ Manage 105: 103-120.

Blaylock MJ, Huang JW (1999) Phytoextraction of metals. In. Raskin I and Ensley BD (eds) Phytoremediation of Toxic Metals: Using plants to clean up the environment, John Wiley \& Sons Inc, New York, NY, pp 53-70.

Capuana M (2011) Heavy metals and woody plants-Biotechnologies for phytoremediation. iForest 4: 715.

Cunningham SD, Ow DW (1996) Promises and prospects of phytoremediation. Plant Physiol 110: 715-719.

Daines RH, Motto H, Chilko DM (1970) Atmospheric lead its relation to traffic volume and proximity to highways. Environ Sci Techn 4: 318-322.

Donnelly PK, Fletcher JS (1994) Potential Use of mycorrhizal fungi as bioremediation agents in bioremediation through rhizosphere technology. Anderson TA, Coats JR (eds), Washington DC: American Chemical Society.

Đorđević D (1996) Sadržaj i poreklo teških metala u vazduhu industrijskog dela Novog Beograda. Magistarski rad, Fakultet za Fizičku hemiju Univerzitet u Beogradu.

Environmental protection agency, Republic of Serbia (2013) Monitoring of land - legal basis, objectives and indicators. /Praćenje stanja zemljišta - zakonski osnov, ciljevi i indikatori, Agencija za zaštitu životne sredine, Republika Srbija.

Gardea-Torresdey JL, Peralta-Videa JR, de la Rosa G, Parsons JG (2005) Phytoremediation of heavy metals and study of the metal coordination by X-ray absorption spectroscopy. Coord Chem Rev 249: 1797-1810. 
Gburčik P, Jović N, Tomić Z, Gburčik V (1994) Uticaj termoelektrana Obrenovac na životnu sredinu područja Obedske bare. U: Aerozagađenje i šumski ekosistemi, CMS i Šumarski fakultet, Beograd. pp 227-237.

Guthner G (1989) Remarks on control of heavy metal emissions in the federal republik of germany. Heavy metal emissions, Prague 24-26.10.1989.

ITRC - Interstate Technology and Regulatory Cooperation Work Group (1999) Phytoremediation decision tree. Interstate Technology and Regulatory Cooperation Work Group. 35 p.

Isajev V, Ivetić V, Rakonjac Lj, Lučić A (2010) Significance of nursery stock production in the processes of rehabilitation of areas under erosion hazard. [In Serbian: Značaj proizvodnje sadnog materijala u procesima revitalizacije erozijom ugroženih površina.] Šumarstvo 3-4: 83-99.

Ivetić V (2015) Reforestation in Serbia: Success or failure? In: Ivetić V, Stanković D (eds) Proceedings: International conference Reforestation Challenges. 03-06 June 2015, Belgrade, Serbia. Reforesta, pp 1-12.

Ivetić V, Vilotić D (2014) The role of plantation forestry in sustainable development. Bulletin of the Faculty of Forestry: 157-180.

Ivetić V, Devetaković J (2016) Reforestation challenges in Southeast Europe facing climate change. Reforesta 1:178-220.

Johnson DL (1980) Health Effects of particulate diesel exhaust emissions. Masters Thesis, University of Texas at Austin, Texas.

Jović D, Medarević M (1995) The potential of forests and forest areas and their importance for the development of the Republic of Serbia. Monograph. [In Serbian: Potencijali šuma i šumskih područja i njihov značaj za razvoj Republike Srbije. Monografija.]

Kadović R, Medarević M (1996) Aerozagađivanja i šumski ekosistemi u Nacionalnom parku Fruška Gora. Specijalistički seminar iz područja ekološkog menadžmenta, Fruška Gora, 19 oktobar 1996.

Kadović R, Knežević M (2002) Heavy metals in forest ecosystems of Serbia. University of Belgrade-Faculty of Forestry, Ministry of protection natural resourse and environmental of Serbia. pp 278. [In Serbian: Teški metali u šumskim ekosistemima Srbije. Šumarski fakultet Univerziteta u Beogradu. Ministarstvo za zaštitu prirodnih bogatstava i životne sredine Republike Srbije].

Kastori R (1990) Necessary microelements: The physiological role and importance in plant production. [Neophodni mikroelementi: Fiziološka uloga i značaj u biljnoj proizvodnji]. Naučna knjiga, Beograd.

Keller T (1985) Bleinflussen alpine tunnelentluftungen bergfohren der umgebung. Strasse und Verkehr 69: 386-389.

Kloke A, Riebartsch K, Lee HO (1966): Verunreinigungen von kulturpflanzen mit blei aus kraftfahrzeugabgasen, S. A. Landw. Forsch. Sh. 20: 119-123.

Krstić B, Stanković D (2006) Efectul poluantilor auto asupra solului si plantelor. Studia Univ. Vasile Goldis Univ Press, Arad Vasile Goldis, Seria St. Vietii 16: 173-177.

Krstić B, Oljača R, Stanković D (2011) Physiology of woody plants. University of Banja Luka, Faculty of Forestry [In Serbian: Fiziologija drvenastih biljaka. Univerzitet u Banjoj Luci, Šumarski fakultet, Banja Luka].

Krstić B, Stanković D, Nikolić N (2008) Effect of traffic on the concentration of PAHs in NP „Fruška Gora”. Journal of Biotechnology \& Biotechnological Equipment: 736-741.

Kurfurst J ECE Project (1989) Heavy metals emissions. Heavy metal emissions, Vol 1, Prague 24-26.10.

Lasat MM (2002) Phytoextraction of toxic metals. A Review of Biological Mechanisms, J Environ Qual 31: 109-120.

Marques APGC, Rangel AOSS, Castro PML (2009) Remediation of heavy metal contaminated soils: Phytoremediation as a potentially promisingclean-up technology. Crit Rev Env Sci Tec 39: 622654.

Motto HL, Daines RH, Chilko DM, Motto CK (1970) Lead in soils and plants: Its relationship to traffic volume and proximity to highways. Environ Sci Technol 4: 231-237.

NAP (2014) National action plan to mitigate the effects of drought and land degradation. Draft, Ministry of Agriculture and environmental protection or Republic of Serbia. 
National inventory of forests of Republic of Serbia (2009) Ministry of Agriculture, forestry and water management, Directorate of Forests. [Nacionalna inventura šuma Republika Srbije (2009) Ministarstvo poljoprivrede šumarstva i vodoprivrede. Uprava za šume Beograd]

Nriagu JO (1979) Global inventory of natural and anthropogenic emissions of trace metals to the atmosphere. Nature 279: 409-411.

Obradović M, Stanković D, Obradović S (2007) Cohabitation of ecology and sustainable development. Šumarstvo 1-2: 107-114. [Sklad ekologje i održivog razvoja. Šumarstvo 1-2: 107-114]

Oljača R, Koleška I, Ilić Hrkić Z, Stanković D (2014) Influence of air pollution on the density of stomata in the studied species sycamore maple and white ash in Brčko district. [In Serbian: Uticaj aerozagadjenja na gustinu stoma ispitivanih drvenastih vrsta javorolisnog platana i bijelog jasena u uslovima Brčko distrikta]. In Mitrić S (ed) Book of abstract: III International Symposium and XIX Scientific Conference of Agronomists of Republic of Srpska. pp 391.

Pacyna J, Munch J (1989) European inventory of trace metal emissions to the atmosphere. Heavy metal emissions, Vol.1, Prague 24-26.10.1989.

Peralta-Videa JR, Lopez ML, Narayan M, Saupe G, Gardea-Torresdey J (2009) The biochemistry of environmental heavy metal uptake by plants: Implications for the food chain. Int J Biochem Cell B 41: 1665-1677.

Pilipović A, Klašnja B, Orlović S (2002) The role of poplars for phytoremediation of soil and groundwater. Topola 169/170: 57-66. [In Serbian: Uloga topola u fitoremedijaciji zemljišta i podzemnih voda]

Ponting C (1991) A new green history of the world. The envoronment and the Collapse of Great Civilisations. Odiseja, Belgrade. [in Serbian]

Prasad MNV, Freitas HMO (2003) Metal hyperaccumulation in plants - Biodiversity prospecting for phytoremediation technology. Electron J Biotechn 6: 225-321.

Primault B (1958) En marge des futures auto rutes. Schwiz Zeit Forstw 109: 37-43.

Spatial plan of Republic of Serbia (1996) Republic Agency for Spatial Planning, Belgrade. [Prostorni plan Republike Srbije iz 1996. Republička agencija za prostorno planiranje, Beograd]

Pulford ID, Watson C (2003) Phytoremediation of heavy metal-contaminated land by trees - a review. Environ Int 29: 529-540.

Raskin I, Smith RD, Salt DE (1997) Phytoremediation of metals: using plants to remove pollutants from the environment. Current Opinion in Biotechnology 8(2): 221-226.

Reichenauer T (2002) Selection of stress-resistant clones of Populus nigra and possible application. In: Van Dam CB, Bordacs S (eds), Proceedings of an International Symposium Europop, Szekszard, Hungary.

Salt DE, Smith RD, Raskin I (1998) Phytoremediation. Annual Review Of Plant Physiology And Plant Molecular Biology 49: 643-668.

Schultz R (1987) Vergleichende Betrachtung des Schwermetallhaushalts verschiedenr waldokosysteme/Waldsterben, ser A 32: 1-217.

Sarić M, Krstić B, Stanković Ž (1991) Physiology of plants. Nauka, Belgrade, pp 538. [In Serbian: Fiziologija biljaka]

Sekulić P, Kastori R, Hadžić V (2003) Soil protection from the degradation. Sciences Institute for Agronomy, Novi Sad.

Sing OV, Labana S, Pandey G, Budhiraja R, Jain RK (2003) Phitoremediation: an overview of metallion decontamination from soil. Appl Microbiol Biot 61: 405-412.

Stanković D, Krstić B, Nikolić N (2008) Effect of trafic on the soil contamination with polyciclyc aromatic hydrocarbons (PAHs). Journal of Biotechnology \& Biotechnological Equipment 22(2): 736-741.

Stanković D, Krstić B, Igić R, Trivan G, Petrović N, Jović Dj (2011) Concentration of pollutants in the air, soil and plants in the area of National Park "Fruška gora" Serbia. Fresenius Environmental Bulletin 20: 44-50.

Stanković D, Krstić B, Oljača R, Šijačić Nikolić M, Vilotić D, Ivetić V. (2013) Lead concentracion (Pb) in different plant species in the area of the protected natrural resource Kosmaj - Beograd. XVII međunarodna eko-konferencija. Zaštita životne sredine gradova i prigradskih naselja Novi Sad, 25-28. septembar 2013.Proceedings. pp 259-269. 
Stanković D, Šijačić-Nikolić M, Ivetić V, Karić D, Veselinović M (2014) Iron (Fe) concentration on the area of Protected natural resourse Kosmaj (Serbia). Fress Environ Bull 24

Stanković D, Ivetić V, Ocokoljić M, Jokanović D, Oljača R, Mitrović S (2015) Manganese concentration in plants of the protected natural resource, Kosmaj, in Serbia. Arch Biol Sci 67: 251-255.

Stanković D, Medarević M, Krstić B, Bjelanović I, Šljukić B, Karić D, Janić M (2013a) Concentration of heavy metals and stand state of sesille oak (Quercus petraea (Matt.) Liebl.) on Avala mountain (Serbia). Carpath J Earth Env 8: 59-66.

Stanković $D$, Božović S, Zečević $R$ (2014a) Plants as indicators of the state of the environment. Ecologica 74: 135-139.

Stanković D, Krstić B, Orlović S,Trivan G, Pajnik Poljak L, Sijačić-Nikolić M (2011a) Woody plants and herbs as bioindicators of the current condition of the natural environment in Serbia. Journal of Medicinal Plants Research 5: 3507-3512.

Stanković D, Krstić B, Knezevic M, Sijačić-Nikolić M, Bjelanović I (2012) Concentrations of heavy metals in soil in the area of the protected natural resource "Avala“ in Belgrade. Fresen Environ Bull 20: 495-502.

Stanković D, Krstić B, Igić R (2005) Nickel concentration in some components of the ecosystem of the National park "Fruška Gora". Šumarstvo 4: 59-71.

Stanković D (2008) Plants and communications. Special edition, Zadužbina Andrejević, Belgrade, pp 96. [In Serbian: Biljke i saobraćaj. Posebna izdanja, Zadužbina Andrejević, Beograd]

Stanković D, Jovanić $P$, Krstić B, Šijačić-Nikolić M, Trivan G, Ivanović S, Vučinić A (2013b) Concentration of Pahs in forest ecosystems of the protected natural resource "Avala". Fresen Environ Bull 22: 136-141.

Stanković D, Krstić B, Igić R (2007) Lead concentrations in woody plants in National park Fruška Gora. Bulletin of Faculty of Forestry, University of Banja Luka 7: 83-97.

Tomić Z (2004 Forest phytocenology. University Book, University of Belgrade-Faculty of Forestry, Belgrade. pp 234. [Šumarska fitocenologija Šumarski fakultet Univerziteta u Beogradu, Beograd, 234]

Trivan G, Stanković D, Jović Dj, Ćirković-Mitrović T (2010) On the path of the sustainable and unsustainable development from Stocholm to Copenhagen. Međunarodna naučna konferencija 2010. Šumski ekosistemi i klimatske promene. Proceedings: 207-213.

Treshow M (1980) Pollution effects on plant distribution. Environ Conserv 7: 279-286.

Tomić Z, Rakonjac Lj, Isajev V (2011) The selection of species for afforestation and land reclamation in Central Serbia. Monograph, Institute for Forestry, Belgrade. pp 148. [In Serbian: Izbor vrsta za pošumljavanje i melioracije u centralnoj Srbiji. Monografija, Institut za šumarstvo, Beograd, str. 133-148]

US EPA (1999) Phytoremediation Resource Guide. U.S. Environmental Protection Agency. EPA542-B-99003. Office of Solid Waste and Emergency Response, Technology Innovation Office, Washington, DC 20460. 56 p.

Šijačić-Nikolić M, Stanković D, Krstić B, Vilotić D, Ivetić V (2012) The potential of different lime tree (Tilia spp) genotypes for phytoextraction of heavy metals. Genetika-Belgrade 44: 537-548. 